\title{
Selection and Organization of Periodicals in the Junior College Library
}

Mr. Smith is librarian and Mrs. Hidden reference librarian, Pasadena (Calif.), $\mathrm{Pub}$ lic Schools.

W HICH periodicals are best suited to the needs of junior college students? Should these periodicals be bound or retained unbound? How extensive a file of back issues should be retained? In an effort to answer these and other related questions, an investigation was recently undertaken in the junior colleges of California in the hope that the results would be worth while and of some practical value to junior college librarians in helping to solve their problems with regard to periodicals. This study, combined with others that have been or may be made throughout the United States, ${ }^{1}$ may help in formulating a scale for evaluating periodicals for junior colleges and also help librarians to adopt certain policies, particularly affecting binding and storage of back issues.

\section{Colleges Investigated}

Fifty-six junior college libraries in the

1 Dillman, Pauline I. "Magazines in the Junior College Library." Junior College Journal, 4:227-31, February 1934. Principles which should be used in selecting periodicals for the junior college and a list of an-

notated periodicals which may be helpful;
Adams, H. M. "Periodicals in the Junior College Library." Junior College Journal, 10:144-46, November 1939. A survey of actual practices in the selection and handling of periodicals in 136 junior college libraries throughout the United States;

Eells, W. C. "Periodicals Read by Junior College Students." Library Quarterly, I 2:474-85, July I942. Results of a questionnaire submitted to 13,498 students in 55 junior colleges located in 22 states as to the periodicals they read frequently and the ones they enjoyed most. state of California were invited to participate in this investigation. Evening colleges and libraries serving a state college as well as the junior college were omitted.

Of the 40 responses received, one junior college has no library but uses the facilities of the high school and public libraries to accommodate its students. Of the remaining 39,35 are public junior colleges and four are private.

\section{Procedure}

Part of this survey may be considered an inventory of the periodical resources in the junior college libraries participating in the study. Actual subscriptions and holdings, bound and unbound, would in themselves constitute some evaluation.

Besides listing actual subscriptions, librarians were asked to evaluate periodicals received, and also to state certain policies as to handling of subscriptions, housing of periodicals and duplication.

The questionnaire consisted of a list of the more common periodicals, with space provided for additions. The librarians were asked to indicate the number of copies currently received, holdings, titles bound and titles retained unbound. The librarians were also asked to indicate their opinions as to the value of the various periodicals in their libraries, whether essential, occasionally used, or unimportant. The word "essential" was used in a broad sense, including those magazines which are bought because 
they are popular with the students and those which are considered essential by the librarian and teachers because of their educational value or usefulness for any other purposes, such as library tools. As was to be expected, this section brought more qualifying remarks and comments than any other part of the questionnaire. Some librarians left this section out entirely.

\section{Number of Periodicals Received}

The highest number of periodicals subscribed to by any college was 352 ; the lowest 28 . The college receiving only 28 periodicals is a small one, a combination high school and junior college. The librarian stated that the budget is to be increased next year and that the magazine subscription list will be tripled.

Almost 75 per cent of the reporting public junior college libraries receive more than Ioo periodicals. Actually there are more in this group because some colleges still permit departments to order their own periodicals and records of these do not show up on the library files. Over 25 per cent of the junior colleges receive more than 200 periodicals. Two-thirds of the colleges receive between 50 and 200 periodicals.

\section{Titles of Periodicals Received}

As was found by Adams ${ }^{2}$ in his investigation of 136 junior college libraries throughout the United States, the number of different titles of periodicals received by all of the reporting junior colleges was largeI I67. Adams found, however, that 47.3 per cent of the titles were received by but a single institution. In this survey it was found that 539 titles ( 46.2 per cent) were received by but a single school, and an additional i 86 titles were received by only two schools. Therefore, although the number of different titles is large, over half (62.I

\footnotetext{
2 Adams, H. M. The Junior College Library Pro. gram. Chicago, ALA, I 940.
}

per cent) were taken by only one or two schools. An additional 96 titles were taken by only three of the reporting junior colleges. These magazines would meet the needs of the single student or groups of students depending on taste and curriculum needs. Eells ${ }^{3}$ reported that although twothirds of the magazine reading of junior college students was included in eight periodicals, there were 453 different periodicals reported as being read frequently or enjoyed and valued, even though by but a single student in many instances. The purchase of these periodicals would seem justifiable since it is the purpose of the library to cater to the needs of leaders and special groups of students as well as to the mass of students. However, a librarian should evaluate carefully a magazine of which he is the sole subscriber of the group, for the money may be used to better advantage some place else.

There were only two periodicals subscribed to by 100 per cent of the reporting junior colleges-National Geographic Magazine and the Reader's Digest. 'Time and the Readers' Guide to Periodical Literature (one combination high school and junior college taking the abridged edition) were received by 38 ( 97.5 per cent) of the libraries.

\section{Holdings}

In contrast to the findings of $\mathrm{Adams}^{4}$ and Bishop ${ }^{5}$ during the I930's, the tendency in junior colleges now is to store back issues of many periodicals.

There were six schools which did not list holdings. Four of them stated no reason for the omission, so it is not known whether they had no holdings of back issues, or simply had no record of holdings. Another school stated that the listing of hold-

3 Eells, op. cit.

5 Adams, op.cit. W. "Library Service in the Junior 5 Bishop, W. W. "Library Service in the Junior
College." Junior College Journal, 5:456-61, May 1935 . 
ings was omitted because its list was not accurate and a check was being made. The other college is newly-established, and although it has most of the magazines to which it has subscribed, the librarian has not yet established a policy concerning storage and binding of periodicals.

A few colleges have no record of the holdings of periodicals which are sent directly to the departments after being checked in by the librarian. In those instances, where the departmental subscriptions are handled directly through the business office, the library usually has no record of the holdings. Although the junior college is receiving and perhaps keeping back issues, these periodicals are lost so far as this investigation is concerned.

There seems to be enough data to show that the trend is definitely toward storage of back issues, so much so that some librarians and educators may feel that some judicious weeding should be done.

The holdings of back issues of the various periodicals received by more than 20 ( 5 I.3 per cent) of the reporting libraries are shown in a comparative table which may be obtained from the authors of this article.

\section{Binding of Periodicals}

Many librarians expressed a desire for help in formulating policies in regard to binding. There is the problem of whether to use available money for the purchase of more titles or to use it for binding. Study of the use of various periodicals, current and back issues, would be needed to determine what periodicals to bind. These figures, however, are not usually available.

The greatest number of titles reported bound by at least one school was 265 . The greatest number of periodicals reported to be bound by any one school was I92. This was also the largest per cent of periodicals bound by any one college -55 per cent.
There was a great variation in the amount of binding, the range being from $o$ to 55 per cent of current subscriptions. Only three schools bind over 50 per cent or more of periodicals. About 7 I per cent of the colleges bind from Io to 40 per cent of periodicals received.

\section{Handling of Subscriptions}

There is a definite trend toward assumption of complete library control over periodical subscriptions for the entire junior college. Twenty-eight of the colleges indicated complete charge of magazine subscriptions for all departments of the school. This amounted to 7 I.8 per cent of the colleges polled. Two of the libraries reported almost complete control, lacking supervision of periodical subscriptions in only one or two departments. One college reported maintenance of a complete record of all issues received by the school, although the handling of the subscriptions was under the control of the business office. Another library reported that it is to assume full control in the near future, with each department now handling its own subscriptions.

\section{Evaluation}

As aforementioned, some librarians omitted the section on evaluation; others stated that they would not subscribe to a magazine if they did not think it worth while; while still others felt that they had not subscribed to certain periodicals long enough to judge them.

In order to have some concrete figures on which to make comparisons, the values of 3, 2 and I were given to "essential," "occasionally used," and "unimportant" respectively. In the comparative table are listed the number of librarians evaluating the various periodicals received by more than 20 colleges. Rated as essential by at least 20 colleges were 2 I titles. 